\title{
INTRACELLULAR CATION EXCHANGES IN ACIDOSIS DUE TO RENAL INSUFFICIENCY. EFFECTS OF ALKALI THERAPY ${ }^{1}$
}

\author{
By J. R. ELKINTON,2 R. D. SQUIRES, ${ }^{3}$ AND R. B. SINGER \\ (From the Chemical Section of the Department of Medicine, the Department of Research Medi- \\ cine, and the Hospital of The University of Pennsylvania, Philadelphia, Pa.)
}

(Submitted for publication October 30, 1950; accepted, February 5, 1951)

Disturbances in the exchanges of certain intracellular electrolytes which occur in patients with metabolic alkalosis, have been described in the previous paper (1). Clues to the direction and magnitude of these disturbances were obtained by calculating from balance measurements the alterations in body fluids produced by replacement therapy. In the present communication the results are presented of a similar study in patients with metabolic acidosis due to renal insufficiency.

Since this study involved the administration of hypertonic solutions of sodium bicarbonate or sodium lactate, it seemed advisable to reassess all of the factors, including those of intracellular transfers, which determine the quantitative effect of such replacement therapy on the total fluid and acid-base equilibrium of these patients. Previous studies have been made of the effects of alkalinizing sodium solutions. Palmer and Van Slyke (2) and later Hartmann and Senn (3) found that the rise in serum bicarbonate was such that the dose of alkali was apparently distributed through a volume equal to two-thirds of the body weight, a fraction which they believed represented the total body water. Since both bicarbonate ions $(4,5)$ and the major portion of sodium ions are not freely diffusible across the cell membrane, some explanation must be sought for the discrepancy between the value stated above and the now commonly accepted

\footnotetext{
1 Laboratory facilities were aided by grants from the National Heart Institute, U.S.P.H.S., the C. Mahlon Kline Fund of the Department of Medicine, and the Committee on the Advancement of Research of the University of Pennsylvania. The help of the laboratory staffs and of the clinical staff of the Hospital is gratefully acknowledged.

2 Established Investigator of the American Heart Association.

${ }^{3}$ Fellow of the Department of Medicine.
}

magnitude of extracellular fluid of 15 to 20 per cent of the body weight (6).

One of the factors which might explain this difference in the data of Palmer and Van Slyke and Hartmann and Senn was the fact that the dose of administered sodium salt was not corrected for that portion which was unabsorbed or excreted. Another factor was the failure to allow for the change in protein anion concentration in red cells and plasma. Since the amount of cation which is buffered by protein changes as $\mathrm{pH}$ is altered, Singer and Hastings (7) have indicated that the effect of administered acid or alkali is more directly measured by the change in "buffer base," which is equivalent to the change in bicarbonate plus protein anion, than by the change in bicarbonate alone. Such calculation applied to the data of Shock and Hastings (8) gives an apparent volume of distribution of orally administered sodium bicarbonate of about 45 per cent of the body weight, instead of the larger percentage obtained by Palmer and Van Slyke.

Since it seems unlikely that these large volumes of distribution of administered sodium bicarbonate or lactate can be explained by excretion or failure of absorption of sodium, intracellular transfers would appear to be involved. Darrow and coworkers (9) observed that in the muscles of rats rendered acidotic experimentally, the intracellular sodium was depleted. On the basis of this finding he has suggested (10) that uptake of sodium by cells is the explanation of the large doses of alkali required to combat clinical acidosis. Our study confirms this hypothesis and reveals that even when the errors of absorption and excretion are eliminated, and when the buffer base is measured, the quantitative results of alkali therapy in this type of acidosis can only be explained by extensive transfers of cations across the cell boundary. 


\section{EXPERIMENTAL MATERIAL AND METHODS 4}

Eight adult patients with metabolic acidosis due to renal insufficiency were studied. The diagnoses are listed in Table I. Four of these patients were in the polyuric phase of uremia and four were oliguric or anuric. The studies extended from two to ten days over the periods during which sodium bicarbonate was being administered by vein or by mouth. Balances were measured and electrolyte and water exchanges were calculated as in the previous paper (1).

In four of the patients during early periods of therapy detailed studies were made of changes in the acid-base equilibrium. This was done by the technic described by Shock and Hastings (11) which involves the micro-determination of $\mathrm{pH}$ and total $\mathrm{CO}_{2}$ content of cutaneous blood. From these values and that of the hematocrit the tension of carbon dioxide $\left(\mathrm{pCO}_{2}\right)$ and the concentration of buffer base ( $[\mathrm{BB}]$ ) were calculated according to the nomogram of Singer and Hastings (7). These changes were then correlated with the data for the corresponding balance periods.

4 The laboratory assistance of Mrs. Helen Lightman and Mrs. Claire Tissari is especially acknowledged.
Since in most of the cases large changes occurred in the urea nitrogen concentration of body fluids, some difficulty was involved in the calculation of transfers of intracellular potassium which were "in excess of nitrogen" or unrelated to catabolism and anabolism of cells. To make this calculation the external nitrogen balance was corrected by a value obtained by multiplying the change in blood urea nitrogen concentration by an assumed value for total body water. Obviously, where the change in blood urea nitrogen concentration is large and the external nitrogen balance is small, the derived value for "excess potassium" can be but a rough approximation. Such a calculation is useful, however, in indicating at least the direction and type of exchanges involved.

\section{RESULTS}

The results are presented in Tables I to III, and in Figures 1 and 2.

Sodium exchanges and acid-base equilibrium. During the administration of sodium bicarbonate, all of the patients were in a strongly positive sodium balance (Table I). The concentration of

TABLE I

External exchanges of water, electrolytes, and nitrogen

\begin{tabular}{|c|c|c|c|c|c|c|c|c|c|c|c|c|c|c|c|c|c|}
\hline \multirow{4}{*}{ Patient } & \multirow{4}{*}{$\begin{array}{l}\text { Age } \\
\text { and } \\
\text { sex }\end{array}$} & \multirow{4}{*}{ Diagnosis } & \multirow{3}{*}{ Period } & \multicolumn{10}{|c|}{ Average daily } & \multirow{2}{*}{\multicolumn{4}{|c|}{ Total period balance* }} \\
\hline & & & & \multicolumn{5}{|c|}{ Intake } & \multicolumn{5}{|c|}{ Urinary output } & & & & \\
\hline & & & & $\mathrm{H}_{2} \mathrm{O}$ & $\mathrm{Cl}$ & $\mathrm{Na}$ & $\mathbf{K}$ & $\mathbf{N}$ & Vol. & $\mathrm{Cl}$ & $\mathrm{Na}$ & $\mathbf{K}$ & $\mathbf{N}$ & $\mathrm{Cl}$ & $\mathbf{N a}$ & $\mathbf{K}$ & $\mathbf{N}$ \\
\hline & & & $\begin{array}{l}\text { day of } \\
\text { study }\end{array}$ & $m l$. & m.eq. & m.eq. & m.eq. & $\mathrm{gm}$. & $m l$. & m.eq. & m.eq. & m.eq. & $g m$. & m.eq. & m.eq. & m.eq. & $g m$. \\
\hline
\end{tabular}

Group I: Polyuric patients

\begin{tabular}{|c|c|c|c|c|c|c|c|c|c|c|c|c|c|c|c|c|c|}
\hline E. G. & $59 \mathrm{~F}$ & Chr. pyelonephritis & $0-4$ & 2,870 & 70 & $221 \pi$ & 82 & 10.7 & 741 & 28 & 40 & 14 & 2.5 & +165 & +725 & +274 & +32.8 \\
\hline C. P.t & $19 \mathrm{M}$ & Chr. glomerulonephr. & $\begin{array}{l}0-1 \\
1-2 \\
\end{array}$ & $\begin{array}{l}4,100 \\
3,200 \\
\end{array}$ & $\begin{array}{l}57 \\
60 \\
\end{array}$ & $\begin{array}{l}226 \\
226 \\
\end{array}$ & $\begin{array}{l}135 \\
135 \\
\end{array}$ & $\begin{array}{l}10.3 \\
10.7 \\
\end{array}$ & $\begin{array}{l}3,775 \\
2,285 \\
\end{array}$ & $\begin{array}{r}130 \\
69 \\
\end{array}$ & $\begin{array}{r}145 \\
82 \\
\end{array}$ & $\begin{array}{l}72 \\
55 \\
\end{array}$ & $\begin{array}{r}17.5 \\
9.1 \\
\end{array}$ & $\begin{array}{r}-80 \\
-10 \\
\end{array}$ & $\begin{array}{r}+75 \\
+142 \\
\end{array}$ & $\begin{array}{r}+55 \\
+80 \\
\end{array}$ & $\begin{array}{r}7.5 \\
+1.6 \\
\end{array}$ \\
\hline H. H. & $70 \mathrm{~F}$ & Lower nephr. nephrosis & $0-7$ & 3,510 & 55 & 124 & 75 & 9.3 & 2,480 & 70 & 96 & 14 & 10.1 & -111 & +185 & +429 & -6.0 \\
\hline A. $\mathrm{T}$. & $38 \mathrm{~F}$ & Tubular insufficiency & $\begin{array}{l}0-3 \\
3-10\end{array}$ & $\begin{array}{l}3,023 \\
3,747 \\
\end{array}$ & $\begin{array}{r}0 \\
99\end{array}$ & $\begin{array}{l}120 \\
108\end{array}$ & $\begin{array}{r}64 \\
117\end{array}$ & $\begin{array}{l}0 \\
4.3\end{array}$ & $\begin{array}{l}1,362 \\
1,802\end{array}$ & $\begin{array}{l}45 \\
88\end{array}$ & $\begin{array}{l}29 \\
93\end{array}$ & $\begin{array}{l}16 \\
42\end{array}$ & $\begin{array}{l}4.2 \\
8.7\end{array}$ & $\begin{array}{l}-141 \\
+67\end{array}$ & $\begin{array}{l}+268 \\
+86\end{array}$ & $\begin{array}{l}+143 \\
+536\end{array}$ & $\begin{array}{l}-12.6 \\
-30.2\end{array}$ \\
\hline
\end{tabular}

Group II: Oliguric and anuric patients

\begin{tabular}{|c|c|c|c|c|c|c|c|c|c|c|c|c|c|c|c|c|c|}
\hline G. D.t & $18 \mathrm{~F}$ & Dissem. lupus & $0-2$ & 1,170 & 23 & 300 & 1 & - & 140 & 5 & 1 & 7 & 一 & -2 & +483 & -20 & - \\
\hline J. R. & $36 \mathrm{M}$ & Nephrosclerosis & $\begin{array}{l}0-1 \\
1-5\end{array}$ & $\begin{array}{l}1,120 \\
1,286\end{array}$ & $\begin{array}{l}36 \\
67\end{array}$ & $\begin{array}{l}251 \\
202\end{array}$ & $\begin{array}{r}2 \\
10\end{array}$ & $\begin{array}{l}0 \\
0.2\end{array}$ & $\begin{array}{l}140 \\
334\end{array}$ & $\begin{array}{l}2 \\
5\end{array}$ & $\begin{array}{l}1 \\
5\end{array}$ & $\begin{array}{r}5 \\
15\end{array}$ & $\begin{array}{l}0.4 \\
1.9\end{array}$ & $\begin{array}{r}+18 \\
+237\end{array}$ & $\begin{array}{r}+244 \\
+777\end{array}$ & $\begin{array}{l}-6 \\
-24\end{array}$ & $\begin{array}{l}-0.5 \\
-7.2\end{array}$ \\
\hline M. B. 8 & $65 \mathrm{M}$ & $\overline{\text { Lower nephr. nephrosis }}$ & $0-6$ & $\overline{1,800}$ & 27 & 111 & $\mathbf{0}$ & 0.5 & 105 & 7 & 12 & 2 & 0.8 & -220 & +359 & -41 & -9.3 \\
\hline I. C.II & $40 \mathrm{~F}$ & $\overline{\text { Lower nephr. nephrosis }}$ & $0-8$ & $\overline{1,505}$ & 24 & 118 & $\mathbf{0}$ & $\mathbf{0}$ & 5 & - & - & - & - & $\overline{-42}$ & +752 & -135 & -9.1 \\
\hline
\end{tabular}

* Balances corrected for small quantities of $\mathrm{Cl}$ and $\mathrm{Na}$ lost in serum drawn for analysis, and for electrolytes lost in gastrointestinal and pleural fluids where indicated.

$\dagger 200 \mathrm{ml}$. of vomitus included in balance.

$\ddagger 600 \mathrm{ml}$. of pleural fluid included in balance.

Gastric drainage removed during last three days included in balance.

II Upper gastrointestinal drainage and electrolytes removed by resin enemata included in balance.

I Given by mouth.

Balance data are expressed per individual period rather than cumulatively. 
TABLE II

Analyses of blood and serum, and changes in the distribution of sodium and potassium between the phases of body fluid

\begin{tabular}{|c|c|c|c|c|c|c|c|c|c|c|c|c|c|}
\hline \multirow{4}{*}{ Patient } & \multirow{3}{*}{ Time } & \multirow{3}{*}{ Weight } & \multirow{2}{*}{\multicolumn{5}{|c|}{ Serum }} & \multirow{3}{*}{$\begin{array}{c}\text { Blood } \\
\text { urea } \\
\mathbf{N}\end{array}$} & \multirow{3}{*}{$\begin{array}{l}\text { Extra- } \\
\text { cellular } \\
\text { volumet }\end{array}$} & \multicolumn{4}{|c|}{ Change in } \\
\hline & & & & & & & & & & & & Pota & ium \\
\hline & & & $\mathrm{CO}_{2}$ & $\mathrm{Cl}$ & $\mathrm{Na}$ & $\mathbf{K}$ & $\mathrm{H}_{2} \mathrm{O}^{*}$ & & & Extracell. & Intracell. & Extracell. & Intracell. \\
\hline & $\begin{array}{l}\text { day of } \\
\text { study }\end{array}$ & kg. & $\underset{\text { per } l .}{m}$. & $\begin{array}{l}\text { meq. } \\
\text { per l. }\end{array}$ & $\begin{array}{l}\text { m.eq. } \\
\text { per l. }\end{array}$ & $\begin{array}{l}\text { m.eq. } \\
\text { per l. }\end{array}$ & $\underset{\text { per } i .}{\operatorname{gm}}$. & $\begin{array}{c}\text { mg. } \\
\text { per cent }\end{array}$ & $l$. & m.eq. & m.eq. & m.eq. & m.eq. \\
\hline
\end{tabular}

Group I: Polyuric patients

\begin{tabular}{|c|c|c|c|c|c|c|c|c|c|c|c|c|c|}
\hline E. G. & $\begin{array}{l}0 \\
4\end{array}$ & $\begin{array}{l}48.7 \\
50.2\end{array}$ & $\begin{array}{l}13.5 \\
23.0\end{array}$ & $\begin{array}{r}101 \\
91\end{array}$ & $\begin{array}{l}129 \\
139\end{array}$ & $\begin{array}{l}4.6 \\
3.6\end{array}$ & 931 & $\begin{array}{r}107 \\
88\end{array}$ & $\begin{array}{c}(8.0) \\
10.4\end{array}$ & +420 & +305 & \pm 0 & +178 \\
\hline \multirow[t]{2}{*}{ C. P. } & \multirow[t]{2}{*}{$\begin{array}{l}0 \\
1 \\
2\end{array}$} & \multirow[t]{2}{*}{$\begin{array}{l}66.0 \\
66.0 \\
66.0\end{array}$} & \multirow[t]{2}{*}{$\begin{array}{l}15.8 \\
21.2 \\
26.5\end{array}$} & \multirow[t]{2}{*}{$\begin{array}{l}97 \\
92 \\
95\end{array}$} & \multirow[t]{2}{*}{$\begin{array}{l}132 \\
136 \\
141\end{array}$} & \multirow[t]{2}{*}{$\begin{array}{l}5.0 \\
5.1 \\
5.0\end{array}$} & \multirow[t]{2}{*}{939} & \multirow[t]{2}{*}{$\begin{array}{l}132 \\
144 \\
144\end{array}$} & \multirow[t]{2}{*}{\begin{tabular}{|c}
$(10.0)$ \\
9.8 \\
9.4
\end{tabular}} & $\begin{array}{l}+15 \\
-10\end{array}$ & $\begin{array}{r}+60 \\
+152\end{array}$ & $\begin{array}{l} \pm 0 \\
-3\end{array}$ & $\begin{array}{r}+86 \\
+79\end{array}$ \\
\hline & & & & & & & & & & +5 & +212 & -3 & +165 \\
\hline H. H. & $\begin{array}{l}0 \\
7\end{array}$ & 二 & $\begin{array}{l}11.7 \\
21.6\end{array}$ & $\begin{array}{r}99 \\
103\end{array}$ & $\begin{array}{l}126 \\
139\end{array}$ & $\begin{array}{l}2.5 \\
2.5\end{array}$ & 942 & $\begin{array}{l}112 \\
104\end{array}$ & $\begin{array}{c}(15.0) \\
13.5\end{array}$ & -15 & +200 & -4 & +428 \\
\hline \multirow[t]{2}{*}{ A. T. } & \multirow[t]{2}{*}{$\begin{array}{r}0 \\
3 \\
10\end{array}$} & \multirow[t]{2}{*}{$\overline{\overline{4}}$} & \multirow[t]{2}{*}{$\begin{array}{r}3.8 \\
13.1 \\
25.6\end{array}$} & \multirow[t]{2}{*}{$\begin{array}{r}120 \\
106 \\
99\end{array}$} & \multirow[t]{2}{*}{$\begin{array}{l}136 \\
134 \\
134\end{array}$} & \multirow[t]{2}{*}{$\begin{array}{l}2.6 \\
2.6 \\
4.1\end{array}$} & \multirow[t]{2}{*}{$\begin{array}{l}936 \\
937 \\
934\end{array}$} & \multirow[t]{2}{*}{$\begin{array}{l}15 \\
39 \\
20\end{array}$} & \multirow[t]{2}{*}{$\begin{array}{r}7.9 \\
7.8 \\
(9.0)\end{array}$} & $\begin{array}{r}-30 \\
+164\end{array}$ & $\begin{array}{r}+298 \\
-\quad 78\end{array}$ & $\begin{array}{l}-1 \\
+17\end{array}$ & $\begin{array}{l}+192 \\
+568\end{array}$ \\
\hline & & & & & & & & & & +134 & +220 & +16 & +760 \\
\hline
\end{tabular}

Group II: Anuric patients

\begin{tabular}{|c|c|c|c|c|c|c|c|c|c|c|c|c|c|}
\hline G. D. & $\begin{array}{l}0 \\
2\end{array}$ & 70.0 & $\begin{array}{l}10.8 \\
20.7\end{array}$ & $\begin{array}{l}88 \\
94\end{array}$ & $\begin{array}{l}116 \\
128\end{array}$ & $\begin{array}{l}7.1 \\
7.1\end{array}$ & 957 & $\begin{array}{l}152 \\
152\end{array}$ & $\begin{array}{c}(15.0) \\
14.1\end{array}$ & +65 & +418 & -7 & $-13 \S$ \\
\hline \multirow[t]{2}{*}{ J. R. } & \multirow[t]{2}{*}{$\begin{array}{l}0 \\
1 \\
5\end{array}$} & \multirow[t]{2}{*}{$\bar{z}$} & \multirow[t]{2}{*}{$\begin{array}{l}16.7 \\
18.9 \\
27.0\end{array}$} & \multirow[t]{2}{*}{$\begin{array}{l}76 \\
75 \\
75\end{array}$} & \multirow[t]{2}{*}{$\begin{array}{l}112 \\
117 \\
131\end{array}$} & \multirow[t]{2}{*}{$\begin{array}{l}4.9 \\
5.3 \\
6.1\end{array}$} & \multirow[t]{2}{*}{$\begin{array}{l}944 \\
942 \\
940\end{array}$} & \multirow[t]{2}{*}{$\begin{array}{r}98 \\
116 \\
148\end{array}$} & \multirow[t]{2}{*}{$\begin{array}{l}(16.0) \\
16.4 \\
19.2\end{array}$} & $\begin{array}{l}+125 \\
+595\end{array}$ & $\begin{array}{r}+119 \\
+182\end{array}$ & $\begin{array}{r}+9 \\
+30\end{array}$ & $\begin{array}{l}+6 \\
-\quad 1\end{array}$ \\
\hline & & & & & & & & & & +720 & +301 & +39 & +5 \\
\hline M. B. & $\begin{array}{l}0 \\
6\end{array}$ & 82.0 & $\begin{array}{l}19.8 \\
28.0\end{array}$ & $\begin{array}{l}84 \\
69\end{array}$ & $\begin{array}{l}131 \\
139\end{array}$ & $\begin{array}{l}4.9 \\
7.1\end{array}$ & $\begin{array}{l}928 \\
921\end{array}$ & $\begin{array}{r}83 \\
138\end{array}$ & $\begin{array}{c}(17.0) \\
17.4\end{array}$ & +210 & +149 & +41 & +6 \\
\hline I. C. & $\begin{array}{l}0 \\
8\end{array}$ & 二 & $\begin{array}{l}17.6 \\
21.6\end{array}$ & $\begin{array}{l}93 \\
76\end{array}$ & $\begin{array}{l}135 \\
143\end{array}$ & $\begin{array}{l}5.3 \\
5.4\end{array}$ & 931 & $\begin{array}{l}116 \\
224\end{array}$ & $\begin{array}{r}(15.0) \\
17.8\end{array}$ & +530 & +222 & +16 & -4 \\
\hline
\end{tabular}

* Calculated from the concentration of serum protein.

$\dagger$ Calculated by changes in chloride balance forward or backward from an assumed extracellular volume (designated by parentheses).

In excess of nitrogen.

8 Total intracellular $\mathrm{K}$, not $\mathrm{K}$ in excess of $\mathrm{N}$.

Time as designated by day indicates end of period at which time serum analyses were made, balances for the period determined, and exchanges calculated.

serum sodium rose in all (Table II). In all of the patients sodium entered the intracellular or "nonchloride" phase (Table II). This increment of intracellular sodium varied from 29 to 108 per cent of the amount of sodium retained, and in four of the eight patients was more than 50 per cent. In three of the eight patients little or none of the sodium was retained in the extracellular phase; consequently, in these patients, the increase in concentration of extracellular cation which was available for the bicarbonate and protein anions was the result primarily of decreases in extracellular water and chloride rather than of an increase in the absolute amount of extracellular sodium. Thus, whether or not there was an increase in the absolute amount of extracellular sodium, all of the 
TABLE III

Acid-base data on cutaneous whole blood

Before and after initial periods of $\mathrm{NaHCO}_{3}$ therapy

\begin{tabular}{|c|c|c|c|c|c|c|}
\hline \multirow[b]{2}{*}{ Patient } & \multirow[b]{2}{*}{ Time } & \multicolumn{3}{|c|}{ Observed data } & \multicolumn{2}{|c|}{ Derived data } \\
\hline & & $\begin{array}{c}\text { Relative } \\
\text { cell } \\
\text { volume }\end{array}$ & $\mathrm{pH}$ & $\underset{\text { content }}{\mathrm{CO}_{2}}$ & $\mathrm{pCO}_{2} \dagger$ & $\begin{array}{l}\text { Buffer } \\
\text { base }\end{array}$ \\
\hline & $\begin{array}{l}\text { day of } \\
\text { study } \$\end{array}$ & $\begin{array}{l}\text { per cent } \\
\text { cells }\end{array}$ & & $\underset{\text { per } l .}{m M}$. & $m m . \mathrm{Hg}$ & $\begin{array}{l}\text { m.eq. } \\
\text { per l. }\end{array}$ \\
\hline C. $\mathrm{P}$. & $\begin{array}{l}0 \\
1\end{array}$ & $\begin{array}{l}19 \\
20\end{array}$ & $\begin{array}{l}7.24 \\
7.34\end{array}$ & $\begin{array}{l}13.2 \\
18.9\end{array}$ & $\begin{array}{l}31 \\
37\end{array}$ & $\begin{array}{l}32 \\
39\end{array}$ \\
\hline A. $T$. & $\begin{array}{l}0 \\
3\end{array}$ & $\begin{array}{l}41 \\
29\end{array}$ & $\begin{array}{l}7.00 \\
7.35\end{array}$ & $\begin{array}{r}4.5 \\
11.2\end{array}$ & $\begin{array}{l}19 \\
22\end{array}$ & $\begin{array}{l}21 \\
33\end{array}$ \\
\hline G. D. & $\begin{array}{l}0 \\
2\end{array}$ & $\begin{array}{l}20 \\
15\end{array}$ & $\begin{array}{l}7.34 \\
7.35\end{array}$ & $\begin{array}{l}10.6 \\
17.9\end{array}$ & $\begin{array}{l}21 \\
33\end{array}$ & $\begin{array}{l}31 \\
37\end{array}$ \\
\hline J. R. & $\begin{array}{l}0 \\
1\end{array}$ & $\begin{array}{l}26 \\
26\end{array}$ & $\begin{array}{l}7.23 \\
7.28\end{array}$ & $\begin{array}{l}12.7 \\
15.7\end{array}$ & $\begin{array}{l}31 \\
35\end{array}$ & $\begin{array}{l}32 \\
36\end{array}$ \\
\hline
\end{tabular}

* Normal range is 20 to $24 \mathrm{mM}$. per 1 .

† Normal range is 35 to $48 \mathrm{~mm}$. $\mathrm{Hg}$.

$\$$ Normal range is 46 to $52 \mathrm{~m}$. eq. per 1 .

$\$$ Days of study correspond to those in Tables I and II.

patients became less acidotic: the $\mathrm{pH}$, the $\mathrm{pCO}_{2}$, and the concentration of buffer base of whole blood all returned toward normal levels (Table III).

Potassium exchanges. The serum concentration of potassium was within or below normal limits in the group of polyuric patients, and was elevated in oliguric patients (Table II). Since potassium was given to the former group alone, only this group exhibited a positive potassium balance (Table I). In the anuric group the negative potassium balance reached large proportions only in Patient I. C. to whom cation exchange resin ene-

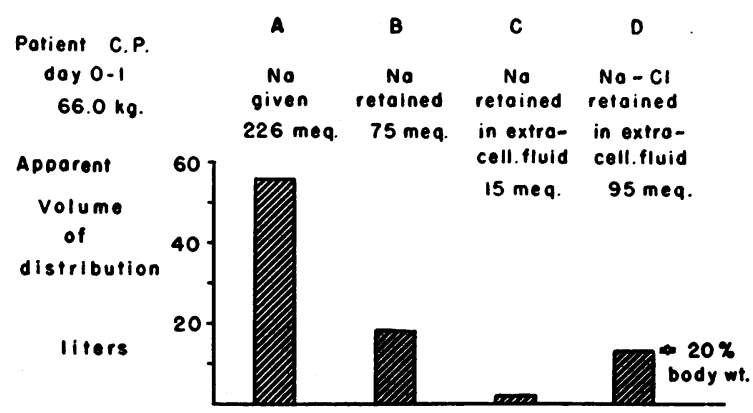

Fig. 1. Apparent Volume of Distribution of Various INCREMENTS OF AdMINISTERED SOdIUM Bicarbonate

Volumes of distribution are calculated by dividing the increment of sodium indicated above the columns by the change in concentration of serum sodium (Columns A and B) or by the change in concentration of buffer base (Columns $\mathrm{C}$ and $\mathrm{D}$ ).

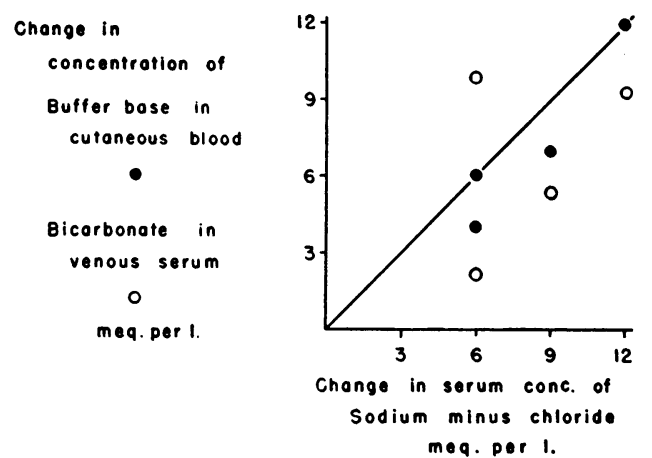

Fig. 2. Changes in Serum Concentration of Sodium Minus Chloride Compared with Those in Buffer Base of Cutaneous Whole Blood and with Those in Bicarbonate of Venous Serum, Induced by the Administration of Sodium Bicarbonate

mata were administered (12). In the anuric patients no significant exchanges of "excess" potassium took place, but in the polyuric patients potassium in excess of nitrogen entered the intracellular phase (Table II). The largest uptake of "excess" potassium was in Patient A. T. and was equivalent to $17.4 \mathrm{~m}$. eq. per kilogram of body weight.

\section{DISCUSSION}

These data support the evidence of Darrow and his co-workers that intracellular sodium may be depleted in at least some types of metabolic acidosis. Certainly administered sodium ion was taken up by the "non-chloride" space in our patients, and to a degree that was surprising. The observation that this portion of sodium varied from one-third to all of the ion retained emphasizes the necessity of taking this phenomenon into consideration when estimating the therapeutic dose of sodium ion under these circumstances. As Darrow predicted, this transfer of sodium into the intracellular phase readily explains the large doses of alkali which on an empirical basis have been found necessary to successfully combat an acidosis in terms of raising a depressed concentration of extracellular bicarbonate or of buffer base.

Thus it is patently absurd to consider in clinical practice that all of the sodium bicarbonate administered, or even retained, enters into the correction of the extracellular electrolyte abnormality which defines the metabolic acidosis. This is well illustrated in Figure 1, in which are shown the volumes of distribution of various increments of so- 
dium bicarbonate administered in one day to $\mathrm{Pa}$ tient C. P. Only part of the sodium given was retained and of this some entered the intracellular phase. Furthermore, the increment of sodium in the extracellular phase had to be corrected by subtracting the balance of chloride since a fall in chloride as well as a rise in sodium concentration increases the base equivalent of bicarbonate and protein in extracellular fluid. When this corrected increment of extracellular sodium minus chloride was divided by the rise in buffer base concentration, a volume of distribution was obtained which approximates a reasonable value for the volume of the extracellular fluid. This is in sharp contrast to the larger values obtained from the data of the previous workers $(2,3)$ mentioned in the introduction above, who failed to take all of these factors into consideration.

These studies also indicate that measurements of changes in concentration of the whole blood buffer base more accurately gauge the effect of therapy on the acid-base balance than do those of bicarbonate or total carbon dioxide. In Figure 2 the changes in serum concentration of sodium minus chloride, induced therapeutically in four of the patients, are compared with the changes in concentration of whole blood buffer base and venous serum carbon dioxide. The correlation is better with the buffer base than with the bicarbonate because the former takes into account the alterations in anionic proteinate due to $\mathrm{pH}$ shifts. Failures to show perfect correlation are accounted for by changes in concentration of other undetermined anions such as phosphates, sulfates, and organic acids, by analytical error, and by the effect of stasis on the carbon dioxide content of venous blood. The calculation of buffer base from $\mathrm{pH}$ and $\mathrm{CO}_{2}$ content of cutaneous blood obviates two of these errors and appears to represent a real improvement in accuracy over the venous serum carbon dioxide concentration in following metabolic disturbances of acid-base balance.

Our data emphasize the extreme difficulty of calculating accurately the amount of sodium required to correct a metabolic acidosis. Even if one can estimate the amount of administered sodium that is likely to be excreted, the increment that will enter the intracellular phase is at present quite unpredictable. Because of these uncertainties in the sodium exchanges, alkali therapy of acidosis can be at best but a matter of intelligent trial and error.

The direction of the exchanges of potassium was not unexpected. Retention of potassium with elevation of the extracellular concentration in renal insufficiency with oliguria and anuria has been described by many workers (13-15). In such cases it is apparent that the potassium intake should be rigidly restricted since viable cells do not readily take up the ion which is in excess in the extracellular phase (15). Potassium deficiency in renal insufficiency is less common but does occur (16). Such a deficiency undoubtedly existed in two of the polyuric patients reported here $(\mathrm{H} . \mathrm{H}$. and $\mathrm{A}$. T.) since potassium was taken up by the cellular phase in excess of nitrogen in amounts quite comparable with those retained in other types of potassium deficiency (17). The mechanism of such a deficiency is not clarified by our present studies. No evidence is presented that tubular secretion occurred in normal or excessive amounts or that tubular reabsorption was diminished. Both of these mechanisms have been implicated in severe renal disease $(18,19)$. A subsequent study of Patient A. T., with the unusual renal lesion of "tubular insufficiency without glomerular insufficiency" (as first described by Albright and co-workers [20]), confirmed the fact that under the stress of the need to excrete excessive amounts of anions, potassium excretion was increased (21). It is probable, however, that in most cases of renal insufficiency in which potassium deficiency occurs, it does so at least in part because of a diminished intake of the ion in food as the result of anorexia and vomiting.

This study re-emphasizes the fact that exchanges of intracellular sodium are not necessarily reciprocal to those of potassium (22). In the polyuric patients sodium ion entered the cellular phase simultaneously with potassium; in the anuric patients a similar transfer of sodium took place without any exchange of "excess" potassium. Apparently, in metabolic acidosis, as in alkalosis (1), the disturbance in acid-base equilibrium is more closely correlated with changes in the sodium content than with changes in the potassium content of the intracellular phase. The patterns of such intracellular disturbances are undoubtedly conditioned by many factors including those of time, renal function, nutrition, and exchanges of water 
and of other ions. As pointed out in the preceding paper (1), any assessment of the relation of these cation transfers to maintenance of ionic electrical neutrality and to osmotic equilibrium within the cells, requires a great deal more data than is available at present. Precise knowledge of these disturbances will only come when these other factors have been more adequately studied and their relationship defined to the metabolic processes which maintain the differential distribution of electrolytes across the cell boundary.

\section{SUMMARY AND CONCLUSIONS}

The exchanges of intracellular sodium and potassium were calculated by the balance technic in eight patients with acidosis due to severe renal insufficiency, during the administration of sodium bicarbonate. On four of the patients acid-base data were obtained.

Sodium entered the intracellular phase in all of the patients in amounts ranging from 29 to 108 per cent of the sodium retained.

Potassium entered the intracellular phase in the four polyuric patients to whom it was given. In the anuric patients to whom no potassium was given because of an elevated extracellular concentration of the ion, no significant exchange occurred of intracellular potassium in excess of nitrogen.

The metabolic acidoses as measured by the buffer base or bicarbonate were corrected in whole or in part in all of the patients.

It is concluded (1) that measurements of the whole blood buffer base give a better index than the $\mathrm{CO}_{2}$ content of changes in this type of acid-base disturbance, (2) that shift of sodium into cells, as well as excretion of sodium and balance of chloride, determine the effect of administered alkali on the acidosis, and (3) that because of the unpredictability of these factors the therapeutic dosage can only be roughly estimated ahead of time.

\section{REFERENCES}

1. Elkinton, J. R., Squires, R. D., and Crosley, A. P., Jr., Intracellular cation exchanges in metabolic alkalosis. J. Clin. Invest., 1951, 30, 369.

2. Palmer, W. W., and Van Slyke, D. D., Studies of acidosis. IX. Relationship between alkali retention and alkali reserve in normal and pathological individuals. J. Biol. Chem., 1917, 32, 499.
3. Hartmann, A. F., and Senn, M. J. E., Studies in the metabolism of sodium $r$-lactate. I. Response of normal human subjects to the intravenous injection of sodium $r$-lactate. J. Clin. Invest., 1932, 11, 327.

4. Rosenbaum, J. D., The influence of alterations in acidbase balance upon transfers of carbon dioxide and bicarbonate in man. J. Clin. Invest., 1942, 21, 735.

5. Wallace, W. M., and Hastings, A. B., The distribution of the bicarbonate ion in mammalian muscle. J. Biol. Chem., 1942, 144, 637.

6. Levitt, M. F., and Gaudino, M., Measurement of body water compartments. Am. J. Med., 1950, 9, 208.

7. Singer, R. B., and Hastings, A. B., An improved clinical method for the estimation of disturbances of the acid-base balance of human blood. Medicine, 1948, 27, 223.

8. Shock, N. W., and Hastings, A. B., Studies of the acid-base balance of the blood. IV. Characterization and interpretation of the acid-base balance. J. Biol. Chem., 1935, 112, 239.

9. Darrow, D. C., Schwartz, R., Iannucci, J. F., and Coville, F., The relation of serum bicarbonate concentration to muscle composition. J. Clin. Invest., 1948, 27, 198.

10. Darrow, D. C., Body-fluid physiology: the relation of tissue composition to problems of water and electrolyte balance. New England J. Med., 1945, 233, 91.

11. Shock, N. W., and Hastings, A. B., Studies of the acid-base balance of the blood. I. A microtechnique for the determination of the acid-base balance of the blood. J. Biol. Chem., 1934, 104, 565.

12. Elkinton, J. R., Clark, J. K., Squires, R. D., Bluemle, L. W., Jr., and Crosley, A. P., Jr., Treatment of potassium retention in anuria with cation exchange resin. A preliminary report. Am. J. M. Sc., 1950, 220, 547.

13. Finch, C. A., Sawyer, C. G., and Flynn, J. M., Clinical syndrome of potassium intoxication. Am. J. Med., 1946, 1, 337.

14. Keith, N. M., and Burchell, H. B., Clinical intoxication with potassium: its occurrence in severe renal insufficiency. Am. J. M. Sc., 1949, 217, 1.

15. Elkinton, J. R., Tarail, R., and Peters, J. P., Transfers of potassium in renal insufficiency. $\mathrm{J}$. Clin. Invest., 1949, 28, 378.

16. Brown, M. R., Currens, J. H., and Marchand, J. F., Muscular paralysis and electrocardiographic abnormalities resulting from potassium loss in chronic nephritis. J. A. M. A., 1944, 124, 545.

17. Tarail, R., and Elkinton, J. R., Potassium deficiency and the role of the kidney in its production. $\mathrm{J}$. Clin. Invest., 1949, 28, 99.

18. Leaf, A., and Camara, A. A., Renal tubular secretion of potassium in man. J. Clin. Invest., 1949, 28, 1526.

19. Burnett, C. H., Shapiro, S. L., Simeone, F. A., Beecher, H. K., Mallory, T. B., and Sullivan, E. R., 
Post-traumatic renal insufficiency. Surgery, 1947, 22, 994.

20. Albright, F., Burnett, C. H., Parson, W., Reifenstein, E. C., Jr., and Roos, A., Osteomalacia and late rickets. The various etiologies met in the United States with emphasis on that resulting from a specific form of renal acidosis, the therapeutic indications for each etiological sub-group, and the relationship between osteomalacia and Milkman's syndrome. Medicine, 1946, 25, 399.

21. Elkinton, J. R., Squires, R. D., and Singer, R. B.: Unpublished study.

22. Elkinton, J. R., Winkler, A. W., and Danowski, T. S., Transfers of cell sodium and potassium in experimental and clinical conditions. J. Clin. Invest., 1948, 27, 74. 